\title{
MICROBIAL COMMUNITIES IN SALT EFFLORESCENCES
}

Leonilla Laiz, Delfina Recio, Bernardo Hermosin and Cesareo Saiz-Jimenez Instituto de Recursos Naturales y Agrobiologia, C.S.I.C., Apartado 1052, E-41080 Sevilla, Spain

Key words: efflorescences, halotolerant bacteria, Bacillus

Abstract: The weathering of stone and masonry results, among other phenomena, in the formation of efflorescences, a deposit of salts not originally evident in the sound material, and composed of a variety of different hygroscopic salts, including carbonates, chlorides, nitrates, sulphates, etc. Thus the deteriorated areas of some monuments can be considered as extremely saline environments, at least in the efflorescences zones. These zones seemed to be a particular niche for investigating halotolerant and/or halophilic bacteria, but only recently a few reports appeared stressing the importance of these types of bacteria. In this paper, bacteria were isolated from samples taken from the efflorescences originated in the Chapel of All Souls, cathedral of Jerez, Spain, and cultured in media with increasing concentrations of halite or epsomite (up to $25 \%$ ). The most frequently isolated genus was Bacillus, followed by Staphylococcus, Kocuria, Micrococcus, Paenibacillus and Arthrobacter. The origin, occurrence and ecology of halotolerant and halophilic bacteria in monuments are discussed.

\section{INTRODUCTION}

Weathering of exposed stone and masonry results from physical, chemical and biological processes, which includes dissolution of carbonates and sulphates, solubilization by leaching of elements from silicates, weathering due to crystallization and hydration pressures, microbial attack by inorganic and organic acids, etc. 
Practically all building walls contain soluble salts, dispersed within the porous materials or locally concentrated. These salts are solubilized and migrate with the water in and out of the stone. The drying out of the solution at the exposed surface results in the formation of efflorescences. The term efflorescence is employed to denote the presence on stone or masonry surfaces of a deposit of inorganic substances not originally evident in the sound material. A description of the different types of efflorescences and the mechanisms of formation on building stones was reported by Charola and Lewin (1979).

Thus, a variety of different hygroscopic salts, including carbonates, chlorides, nitrates, sulphates, etc. can be found on the surfaces of decayed monuments. This means that some particular monument areas can be considered as extremely saline environments, at least in the efflorescences zones, but the salinity is not necessarily based on halite, as sometimes epsomite or gypsum are the main components.

Bacteria have adapted to growth in many different niches. One of them, the hypersaline environment is characterized by high concentrations of salts. Usually this refers to waters and the term hypersaline waters defines those which have concentrations of salts higher than seawater. Considerable research has been carried out on halophilic bacteria in relation to these environments (Rodriguez-Valera, 1988a; Javor, 1989; Vreeland and Hochstein, 1992). Comparatively, very little information exists for terrestrial environments.

In high saline niches, halotolerant bacteria and Archaea can thrive. Until recently Archaea were known only as inhabiting hostile environments (hot springs, solar ponds and saturated brines) where there is little microbial competition (Vreeland and Hochstein, 1992). To this fact also contributed that laboratory cultivation rarely included media with high salt concentrations and as a consequence this group tended to be overlooked.

Halotolerant bacteria, those which grow better without significant amounts of halite in their media, but can also grow at concentrations higher than those of seawater, can therefore be present in active form in saline environments and efflorescences (Incerti et al., 1997). Although efflorescences have a chemical origin, due to migration and crystallization of soluble salts (Mora et al., 1977), a biological origin, due to bacterial growth, was suggested by Lazar (1971) and Bassi and Giacobini (1973).

Lazar (1971) reported that large zones of the nave and altar paintings from the Cozia monastery (Romania) were covered by a whitish fairly adherent powder. The painting zones affected by the whitening phenomenon, which usually completely masked the painting was populated by numerous bacteria, as demonstrated both microscopic preparations of the powder scrapped off from the surface and inoculations on culture media. Of 94 
isolates, the most abundant genera were Bacillus, Arthrobacter, and Micrococcus. Sporogenous forms belonging to various species of the genus Bacillus predominated (32\% of isolates). Almost half of the tested isolates reproduced the phenomenon when inoculated as culture suspensions on undamaged zones of the paintings, the most active being Bacillus pumilus, Micrococcus roseus and Arthrobacter sp. The powdery whitening was a consequence of the introduction of central heating into the monastery and the microclimate modification.

Further, Lazar and Dumitru (1973) reported that the frescoes affected by the efflorescence phenomenon from 10 monasteries of northern Moldavia were populated by a rich bacterial flora made up of representatives of the genera Bacillus, Pseudomonas and Arthrobacter. Of 117 isolates, 60 were Bacillus species (51\%), 17 Arthrobacter, (15\%) and 16 Pseudomonas (14\%). As the authors previously demonstrated the capacity of bacteria to produce efflorescences, they considered that these genera should not be overlooked in the explanation of the causes of the blanching phenomenon of the frescoes.

Saiz-Jimenez and Samson (1981) studied the efflorescences of the frescoes of the monastery of Santa Maria de la Rabida (Spain), and identified gypsum as the most abundant salt, with minor amounts of calcium chloride, sodium chloride, potassium chloride, quartz and silicates. The most abundant bacterium was Micrococcus luteus, but species of the genera Bacillus, Pseudomonas, and Streptomyces were also identified. Sulphur oxiding and reducing bacteria in amounts exceeding those indicating biological attack to monuments (Tiano et al., 1975) were recorded.

In a recent study, Incerti et al. (1997) investigated the bacteria present in the efflorescences from a calcarenite monument. More than $40 \%$ of the isolates from cultures with high salt concentrations were species of the genus Bacillus.

Although the presence of bacteria in mural paintings efflorescences was reported more than 25 years ago, it was only recently that efflorescences (Incerti et al., 1997) and deteriorated mural paintings (Rölleke et al., 1996) were considered as a potential interesting habitat for Archaea. Until now no cultivated halophiles were isolated from monuments, although, recently, Rölleke et al. (1998) detected and identified an Archaeal community within the deteriorated 13th century mural paintings in the chapel of the Herberstein Castle (Austria). The authors used denaturing gradient gel electrophoresis (DGGE) of PCR-amplified DNA encoding 16S rRNA. Total DNA was extracted from the wall painting material and the DNA fragments amplified with Archaeal specific primers. Six out of ten analysed samples showed the presence of Archaeal 16S rDNA fragments, identified as members or close relatives of the genus Halobacterium. This has important implications in the 
general ecological significance of Archaea on monuments with an considerable production of efflorescences.

The present study investigates the ecology of halotolerant and/or halophilic bacteria present in the deteriorated Chapel of All Souls in the Jerez Cathedral.

\section{THE CATHEDRAL OF JEREZ}

The cathedral of Jerez was constructed, with calcarenite from the quarries of Puerto de Santa Maria, between 1695 and 1778, when it was inaugurated. However, other works were carried out from 1780 onward, such as the construction of the Sacristy in 1783, and between 1788 and 1808 the construction of the Ciborium Chapel, anteroom to the Sacristy, Chapter Hall and Library. The construction progressed slowly until 1849 when work was definitively discontinued. In the present century restoration works were carried out in 1964, in the 70's, and between 1983-1986.

As a consequence of the studies carried out during the last restoration period, Rodriguez-Gordillo et al. (1988) reported that the calcarenite showed alteration phenomena in the west facing parts, with deep cavities in the ashlars. Other, even more obvious alteration phenomena were the mechanical fractures in the stone of the dome due to the pressure of the iron anchors of the railings, and the serious powdering of the calcarenite.

In addition, along the time, the east façade was markedly affected by dampness and the stone reredos of the Chapel of All Souls (now Chapel of the Resurrection) had a snowy appearance due to white efflorescences. Although in present times these are periodically cleaned off, it reappears.

Recent analysis of the efflorescences by X-ray diffraction revealed that the main component is hexahydrite $\left(\mathrm{MgSO}_{4} \cdot 6 \mathrm{H}_{2} \mathrm{O}\right)$, accompanied by calcite, gypsum and quartz (Incerti et al., 1997). There are several hydrated phases of magnesium sulphate. The first one, precipitating from a saturated solution and at temperatures below $60^{\circ} \mathrm{C}$, is epsomite $\left(\mathrm{MgSO}_{4} \cdot 7 \mathrm{H}_{2} \mathrm{O}\right)$. Dehydration of epsomite originates hexahydrite. The predominance of one over other depends on the relative humidity. The hexahydrite identified in the studied samples arise from epsomite dehydration, which could be produced in the cathedral walls or after sampling and transport to the laboratory. However, epsomite was the main component of the efflorescences in the sampling carried out in 1983 (Rodriguez-Gordillo et al., 1988).

About $75 \%$ of the efflorescence powder is soluble in water, due mainly to hydrated magnesium sulphate. Ion chromatography revealed that, in addition, nitrates amounting to $0.5 \%$ and chlorides to $0.3 \%$ are present. The X-ray analysis of the insoluble residue indicated the presence of calcite, quartz and 
poorly crystallized hydromagnesite $\left[\mathrm{Mg}_{5}\left(\mathrm{CO}_{3}\right)_{4}(\mathrm{OH})_{2} \cdot 4 \mathrm{H}_{2} \mathrm{O}\right]$. Infrared spectrum of the residue matched those of artificial hydromagnesite (Van der Marel and Beutelspacher, 1976).

Hydromagnesite is recognized as the final-phase mineral in a $\mathrm{Mg}$-rich mineral sequence in many caves and its formation related to $\mathrm{Mg}$-enriched solutions and low $\mathrm{P}_{\mathrm{CO} 2}$ values. These conditions are consistent with highly alkaline waters and high evaporation conditions (Cañaveras et al., 1999). Hydromagnesite crystals were found in Altamira Cave partly embedded in biofilms, and microbial activity was suggested to be involved in the precipitation of hydromagnesite deposits.

In a previous study, several samples of mortars were analysed and yielded, as main components, gypsum, calcite, quartz and lower amounts of epsomite. Concerning the possible origins of the epsomite, the quarry stone had values of $0.02-0.04 \%$ of sulphates ( $\mathrm{MgO}$ was $0.5 \%$ ), and the Pliocene bedrock supporting the cathedral foundation contained $0.02 \%$ sulphates (RodriguezGordillo et al., 1988).

Both the narrow street, the east-facing orientation of the external Chapel walls and the fact that the cathedral is built on the bank of a stream contribute to the problem of dampness, although the origin of epsomite should probably be found in the composition of the mortar, with a high amount of magnesium salts. The joints of the ashlars, made with mortar, are completely impregnated with dampness due to the hygroscopicity of the soluble salts, evidencing a clear liquid film. The high solubility of magnesium sulphate means that it is readily dissolved in the processes of water recirculation inside the stone and mortar, through the walls of the building.

\section{ISOLATION TECHNIQUES AND CULTURE CONDITIONS}

Efflorescences from the right side of the Chapel of All Souls were collected in sterile tubes. One $\mathrm{g}$ of each sample was added to distilled water and cultured in media with increasing concentrations of halite or epsomite (up to $25 \%$ ). Culture media used in this study were previously described (Rodriguez-Varela et al., 1981).

\section{BACTERIAL IDENTIFICATION}

Total cellular fatty acid methyl esters (FAME) were analyzed using the MIDI system in accordance with the protocols for cultures grown on solid medium and instrument specifications recommended by Microbial 
Identification System, Neward, USA. By using this commerciallly available gas chromatograph-software system, we obtained FAME profiles which were identified automatically by comparison with the Sherlock Standard Aerobe database. The dendrogram programme was used to determine FAME similarity among groups of bacteria (Gonzalez et al., 1999).

\section{RESULTS AND DISCUSSION}

The Chapel of All Souls has a long history of continuous production of epsomite efflorescences, the higher amounts being observed in the year 1983. Subsequently, the efflorescences were removed periodically in a routine cleaning process. The existence for long time of magnesium salts and their hygroscopicity undoubtedly could have selected a specific community adapted to growing in this high saline environment and it was expected that the bacteria present in efflorescences should mainly be halotolerant bacteria, with a lower, if any, representation of halophilic bacteria.

The existence of a considerable number of bacteria in efflorescences of monuments was already reported by Saiz-Jimenez (1982), the colony forming units (cfu) amounting up to $2 \times 10^{6} \mathrm{cfu} / \mathrm{g}$ of sample in the frescoes of the monastery of Santa Maria de la Rabida (Spain).

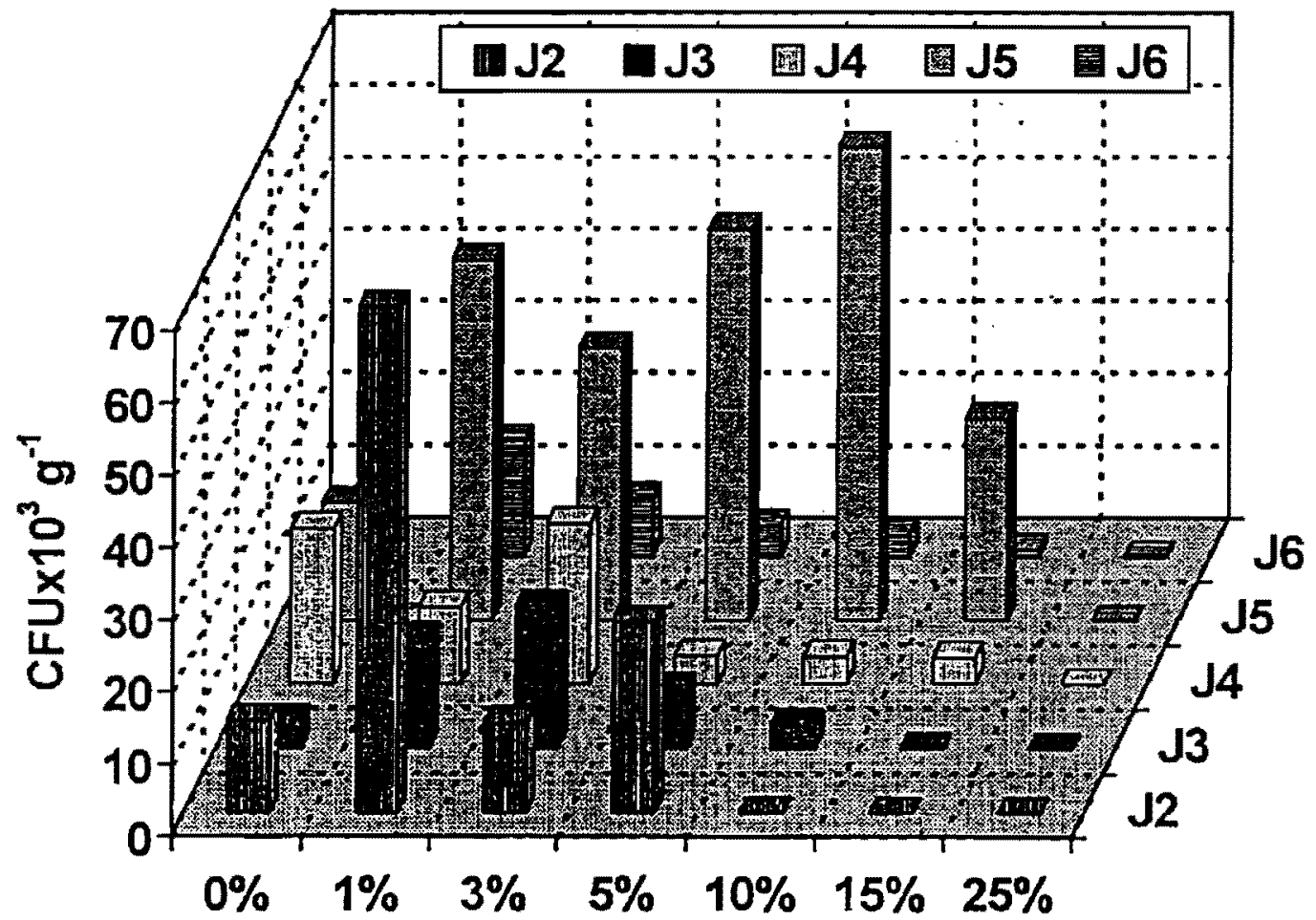

TSA + HALITE

Figure 1. Colony forming units in samples inoculated in TSA+ halite 
In the chapel of the cathedral the bacterial population ranged from 3.8 to $21.6 \times 10^{3} \mathrm{cfu} / \mathrm{g}$ in culture media without halite, measured after $72 \mathrm{~h}$ of incubation. Salinity concentrations from 0.9 to $15 \%$ of halite generally increased the number of cfu with respect to medium without halite (54.3 to $\left.70.7 \times 10^{3} \mathrm{cfu} / \mathrm{g}\right)$. However, the highest salinity concentrations reduced the population, except for sample $\mathrm{J}-5$, in which the population obtained with 10 $\%$ halite was higher $\left(65.6 \times 10^{3} \mathrm{cfu} / \mathrm{g}\right)$ than for other ranges (Figure 1). Interestingly, in this sample, the lowest amount was obtained in the medium without halite. Estimation of the population present in the media with increasing concentrations of epsomite showed similar trends. In this case, the highest numbers were obtained for sample J-3 at $10 \%\left(33.6 \times 10^{3} \mathrm{cfu} / \mathrm{g}\right)$ and $\mathrm{J}-5$ at $5 \%$ epsomite $\left(48.3 \times 10^{3} \mathrm{cfu} / \mathrm{g}\right)$ as shown in Figure 2 . The estimation of the population growing with epsomite was considered necessary and complementary to the estimation with halite because of the specific composition of the efflorescences.

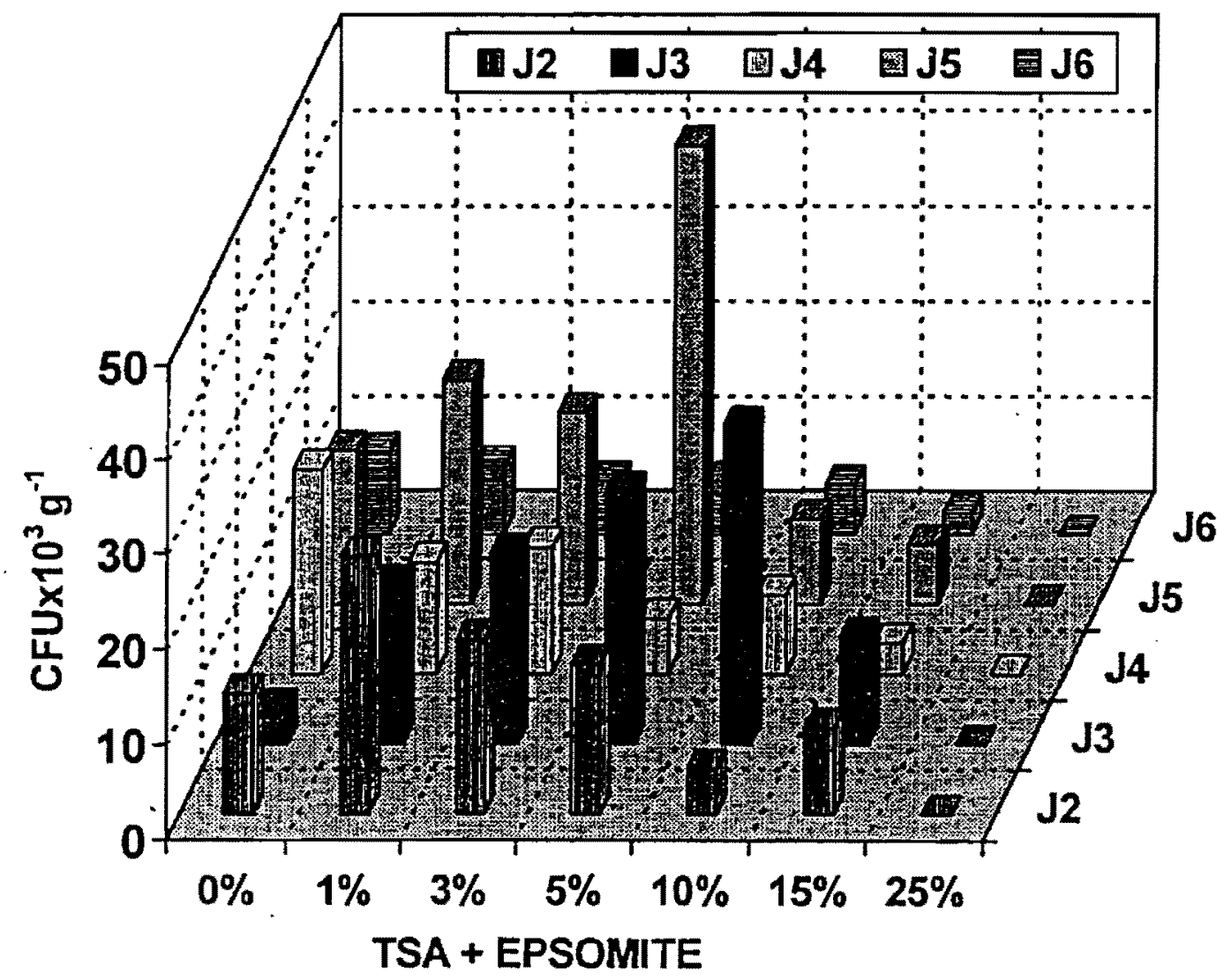

Figure 2. Colony forming units in samples inoculated in TSA + espomite

Although after $72 \mathrm{~h}$ of incubation bacteria did not appear at the highest salt concentrations (25\%), two isolates were obtained after 15 days, indicating a poor and slow growth, which is normal for such a high salt concentration. Attempts to further cultivation were unsuccessful. 
The isolates were characterized and identified using fatty acid analysis. Numerical analysis dendrograms were constructed for each sample and joined as shown in Table 1, which shows the grouping and identification of the isolates from efflorescences.

Table 1. Grouping and identification of 63 isolates from efflorescences samples

\begin{tabular}{|c|c|c|c|c|c|c|}
\hline \multirow[t]{2}{*}{ Cluster } & $\mathrm{J} 2$ & $\mathrm{~J} 3$ & $\mathrm{J4}$ & $\mathrm{J} 5$ & $\mathrm{~J} 6$ & \multirow{2}{*}{$\begin{array}{l}\text { Identification with the } \\
\text { TSBA library* }\end{array}$} \\
\hline & \multicolumn{5}{|c|}{ Number of isolates } & \\
\hline $\mathrm{AA}$ & & 1 & & & 2 & Kocuria sp. \\
\hline$A B$ & & 2 & & & & Staphylococcus haemolyticus \\
\hline $\mathrm{AC}$ & & & 3 & & & No match \\
\hline $\mathrm{AD}$ & 2 & & & & & Bacillus sp. \\
\hline $\mathrm{AE}$ & 1 & 1 & & & & Bacillus pumilus $\mathrm{GC}$ subgroup $\mathrm{B}$ \\
\hline $\mathrm{AF}$ & & 1 & & & 1 & Bacillus freudenreichii \\
\hline AG & 1 & 2 & 2 & & 2 & Bacillus licheniformis \\
\hline $\mathrm{AH}$ & & & & & 1 & Bacillus subtilis \\
\hline $\mathrm{AI}$ & & & 1 & & & Bacillus amyloliquefaciens \\
\hline $\mathrm{AJ}$ & & & 1 & & & Bacillus anthracis \\
\hline $\mathrm{AK}$ & & & & & 1 & Bacillus cereus \\
\hline $\mathrm{AL}$ & & & 1 & & & No match \\
\hline AM & & & & 1 & & Micrococcus halobius \\
\hline AN & & 2 & & & 1 & Bacillus / Paenibacillus \\
\hline $\mathrm{AO}$ & 1 & & & & 1 & Arthrobacter sp. \\
\hline AP & & 2 & & & & Staphylococcus sp. \\
\hline$A Q$ & & 1 & 1 & & & Arthrobacter / Bacillus \\
\hline $\mathrm{AR}$ & & & 1 & & 1 & Bacillus licheniformis \\
\hline AS & & 2 & & & & Staphylococcus cohnii \\
\hline AT & & & 3 & & & Bacillus licheniformis \\
\hline $\mathrm{AU}$ & & 2 & & & & No match \\
\hline AV & 1 & & & & & Micrococcus sp. \\
\hline AW & & & & 2 & & Paenibacillus sp. . \\
\hline$A X$ & & 2 & & 1 & & Bacillus sphaericus GC subgroup III \\
\hline AY & & & 2 & & & Bacillus brevis \\
\hline $\mathrm{AZ}$ & & 1 & & 1 & 1 & No match \\
\hline BA & & 1 & 1 & 2 & & Bacillus sp. \\
\hline BB & 1 & & 1 & & & Bacillus megaterium \\
\hline Unclustered & & & & 1 & & \\
\hline
\end{tabular}

* Identification is given for each cluster, unless the similarity with the TSBA database is lower then 0.300 . If clusters contain strains that are assigned to two genera, both names are reported. If clusters contains strains assigned to several species of the same genus, only the genus name is given.

The endospore-forming isolates were mainly Bacillus species. The genus Bacillus is the most abundant in normal and hypersaline soils, amounting for up to $67 \%$ and $19 \%$, respectively (Rodriguez-Valera, 1988b), and in efflorescences from Romanian monasteries (Lazar and Dumitru, 1973). This genus is virtually absent in hypersaline waters. Bacillus encompasses the rod- 
shaped bacteria capable of aerobically forming endospores that are more resistant than vegetative cells to heat, drying, and other destructive agents. Use of fatty acid analysis resulted in the identification of 7 strains of $B$. licheniformis, 3 of $B$. megaterium, and 1 strain each of $B$. anthracis, $B$. athrophaeus, $B$. marinus, $B$. pumilus, $B$. subtilis, $B$. cereus, $B$. amyloliquefaciens, $B$. sphaericus and $B$. brevis (Table 1). The genera Staphylococcus, Kocuria, Micrococcus, Paenibacillus and Arthrobacter were also represented, with 3 strains of $S$. cohnii and 2 of $K$. varians. Thirty strains were not identified, which represented $48 \%$ of the isolates.

A general characteristic of hypersaline (aquatic) environments is that they are extreme environments and therefore species diversity is low, and some taxonomic groups are missing. However, a large microbial population was found in hypersaline soils with cell numbers ranging from $10^{3}-10^{6}$ per gram of soil. Almost all the organisms isolated were halophilic eubacteria with a remarkable euryhaline response (Rodriguez-Valera, 1988b). Similar data were obtained for the efflorescences.

Bacteria are frequently exposed to stresses due to limitations and changes in nutrient availability, temperature, salinity, etc. and their persistence in the environment is to a great part determined by their capacity to endure these stresses. Osmotic adaptation of halophilic and halotolerant bacteria requires osmoadaptation strategies. While Archaea tolerate high cytoplasmic concentrations of $\mathrm{KCl}$, the $\mathrm{KCl}$-type strategy, the organic-osmolyte type is widespread among aerobic eubacterial halophiles (Galinski, 1993). Organic osmolytes responsible for osmotic balance and compatible with the cells' metabolism have been named compatible solutes, the most important being glycine betaine, ectoines, proline, $N$-acetylated diamino acids and $N$ derivatized glutamine amides. Most of these compounds have been found in bacilli which would explain the abundance of Bacillus species in efflorescences. Thus, the ability to synthesize ectoine is very common among aerobic heterotrophic eubacteria including Gram-positive cocci and Bacillus species; proline was originally considered the typical solute of halophilic Bacillus species, and a screening of halophilic/halotolerant bacilli and related species revealed that the majority of species produced ectoine, either alone or in combination with proline and/or acetylated diamino acids (Müller, 1991).

In the biosphere, bacteria can act as agents which disperse, fractionate or concentrate material. When functioning as dispersion agents, they can promote dissolution of insoluble minerals. As concentrating agents they can accumulate inorganic material via intra or extracellular deposition, and produce biomineralisation. This is the process through which organisms become involved in the formation of minerals. It is known that organisms form more than 60 biogenically different minerals. 
It is well-known that bacteria are able to precipitate calcite and other minerals such as aragonite, struvite, bobierrite, apatite, etc. (Rivadeneyra et al., 1992). In this respect, the production of calcite crystals by soil bacteria has been considered a general phenomenon. Many bacteria, including $B$. pumilus, B. subtilis, B. megaterium, B. cereus, B. bulgaricus, B. globigii, Pseudomonas aeruginosa, P. fluorescens, Serratia spp., Citrobacter spp., Azotobacter spp., etc., formed calcite crystals on solid media containing sodium acetate (Boquet et al., 1973).

Rivadeneyra et al. (1993) found that 26 moderately halophilic strains of Bacillus isolated from a saline soil precipitated magnesium calcite, aragonite, monohydrocalcite and dolomite in varying proportions. The formation of calcium carbonate by some moderately halophilic bacteria was also observed by Del Moral et al. (1987). Optimum salt concentration for precipitation was $10 \%$, precipitation decreasing at both 20 and $2.5 \%$ salt concentration.

Recently, Laiz et al. (1999) and Canaveras et al. (1999) studied the formation of calcite, aragonite and hydromagnesite in caves. The presence of some of these minerals was highly suggestive of a microbially-mediated precipitation. To this end, crystal formation with all isolated bacteria from dripping waters and ceiling rock was tested. The number of isolates precipitating crystals ranged from 15 to $44 \%$ of all isolates, among which $B$. cereus, B. sphaericus, Streptomyces rishiriensis, Chryseomonas luteola, Flavimonas oryzihabitans, Serratia liquefaciens, Xanthomonas maltophilia, Acinetobacter sp. and Amycolatopsis sp. were identified. Crystal composition of the precipitate produced by cultures of Acinetobacter sp. resulted to be vaterite $(85 \%)$ and calcite $(15 \%)$. Although calcite was precipitated by different genera of bacteria, vaterite is highly unstable and is rarely found. Lowenstam (1981) only reported vaterite in Rhodophyta, in addition to a few animal taxa.

To what extent the above reported data can be extrapolated to nature? Lazar (1971) inoculated a dense bacterial suspension $\left(3-4 \times 10^{12}\right.$ cells $\left./ \mathrm{ml}\right)$ on undecayed frescoes zones and reproduced efflorescence formation. Although the studies have stressed the precipitation of crystals in culture media by aquatic and terrestrial bacteria (Laiz et al., 1999), this process needs to be proved in vivo, because the conditions used in the laboratory are far different from those that these bacteria find in their natural habitat. Furthermore, the sources of carbon and energy in culture media probably are different and exceed those available in nature. Although the ecology and physiology of bacteria in efflorescences is relatively unknown, the reported data indicate the presence of halotolerant bacteria, particularly Bacillus species, but more work is needed to ascertain the role of these bacteria in monuments. In addition, search for Archaea in deteriorated monuments should be carried out as there 
is an increasing evidence that these could be an appropriate environments for colonisation by and growth of these microorganisms.

\section{ACKNOWLEDGEMENT}

This work was supported by the European Commission, project ENV4CT98-0705.

\section{REFERENCES}

Bassi, M. and Giacobini, C. 1973. Scanning electron microscopy: a new technique in the study of the microbiology of work of art. Int. Biodet. Bull. 9: 57-68.

Boquet, E., Boronat, A. and Ramos-Cormenzana, A. 1973. Production of calcite (calcium carbonate) crystals by soil bacteria is a general phenomenon. Nature 246: 527-528.

Cañaveras, J.C., Hoyos, M., Sanchez-Moral, S., Sanz-Rubio, E., Bedoya, J., Soler, V., Groth, I., Schumann, P., Laiz, L., Gonzalez, L and Saiz-Jimenez, C. 1999. Microbial communities associated with hydromagnesite and nedle-fiber aragonite deposits in a karstic cave (Altamira, Northern Spain): Geomicrobiol. J. 16: 9-25.

Charola, A.E. and Lewin, S.Z. 1979. Efflorescences on building stones-SEM in the characterization and elucidation of the mechanisms of formation. SEM/1979/, SEM, Inc AMF OHare, IL 60666 p. 379-387

Del Moral, A., Roldan, E., Navarro, J., Monteoliva-Sanchez, M. and Ramos-Cormenzana, A. 1987. Formation of calcium carbonate crystals by moderately halophilic bacteria. Geomicrobiol. J. 5: 79-87.

Galinski, E.A. 1993. Compatible solutes of halophilic eubacteria: molecular principles, water-solute interaction, stress protection. Experientia 49: 487-496.

Gonzalez, I, Laiz, L., Hermosin, B., Caballero, B., Incerti, C. and Saiz-Jimenez, C. 1999. Bacteria isolated from rock art paintings: the case of Atlanterra shelter (south Spain) J. Microbiol. Meth. 36: 123-127.

Incerti, C., Blanco-Varela, M.T., Puertas, F. and Saiz-Jimenez, C. 1997. Halotolerant and halophilic bacteria associated to efflorescences in Jerez cathedral. In F. Zezza (ed.), Origin, Mechanisms and Effects of Salts on Degradation of Monuments in Marine and Continental Environments, Protection and Conservation of the European Cultural Heritage Research Report $\mathrm{n}^{\circ} 4$ p. 225-232.

Javor, B. 1989. Hypersaline Environment: Microbiology and Biogeochemistry. SpringerVerlag, Berlin.

Laiz, L., Groth, I., Gonzalez, I. and Saiz-Jimenez, C. 1999. Microbiological study of the dripping waters in Altamira cave (Santillana del Mar, Spain). J. Microbiol. Meth. 36: 129-138.

Lazar, I. 1971. Investigations on the presence and role of bacteria in deteriorated zones of Cozia monastery painting. Rev. Roum. Biol. Bot. 16: 437-444.

Lazar, I. and Dumitru, L. 1973. Bacteria and their role in the deterioration of frescoes of the complex of monasteries from northern Moldavia. Rev. Roum. Biol. Bot. 18: 191-197. Lowenstam, H.A. 1981. Minerals formed by organisms. Science 211: 1126-1131. 
Mora, P., Mora, L. and Philippot, P. 1977. La Conservation des Peintures Murales. Editrice Compositori, Bologna.

Müller, E. 1991. Kompatible Solute und Prolingewinnung bei halophilen und halotoleranten Bacilli. Ph. D. Dissertation. Universität Bonn.

Rivadeneyra, M.A., Delgado, R., Delgado, G., del Moral, A., Ferrer, M.R. and RamosCormenzana, A. 1993. Precipitation of carbonates by Bacillus sp. isolated from saline soils. Geomicrobiol. J. 11: 175-184.

Rivadeneyra, M.A., Perez-Garcia, I. and Ramos-Cormenzana, A. 1992. Struvite precipitation by soil and fresh water bacteria. Curr. Microbiol. 24: 343-347.

Rodriguez-Gordillo, J., Martin-Vivaldi Martinez, J.A. and Saiz-Jimenez, C. 1988. Estudio de los procesos de alteración, ensayos de envejecimiento acelerado y respuesta al tratamiento con diversos agentes preservantes, de los materiales pétreos de la cúpula de la Colegiata de Jerez de la Frontera (Cádiz). Congreso Geológico de España, Comunicaciones 2: 341-343.

Rodriguez-Valera, F. 1988a. Halophilic Bacteria. CRC Press, Boca Raton, Florida. Rodriguez-Valera, F. 1988b. Characteristics and microbial ecology of hypersaline environments. In Halophilic Bacteria, F. Rodriguez-Valera (ed.), CRC Press, Boca Raton, Florida p. 3-30.

Rodriguez-Valera, F., Ruiz-Berraquero, F. and Ramos-Cormenzana, A. 1981. Characteristics of the heterotrophic bacterial populations in hypersaline environments of different salt concentrations. Microb. Ecol. 7: 235-243.

Rölleke, S., Muyzer, G., Wawer, C., Wanner, G. and Lubitz, W. 1996. Identification of bacteria in the biodegraded wall painting by denaturing gradient gel electrophoresis of PCR-amplified gene fragments coding for 16S rRNA. Appl. Environ. Microbiol. 62: 2059-2065.

Rōlleke, S., Witte, A., Wanner, G. and Lubitz, W. 1998. Medieval wall paintings-a habitat for Archaea: identification of Archaea by denaturing gradient gel electrophoresis (DGGE) of PCR-amplified gene fragments coding for $16 \mathrm{~S}$ rRNA in a medieval wall painting. Int. Biodet. Biodeg. 41: 85-92.

Saiz-Jimenez, C. 1982. Causas del deterioro de los murales de Daniel Vázquez Díaz, Monasterio de Santa María de la Rábida, Huelva. Mundo Científico 18: 1007-1011.

Saiz-Jimenez, C. and Samson, R.A. 1981. Microorganisms and environmental pollution as deteriorating agents of the frescoes of the monastery of Santa Maria de la Rabida, Huelva, Spain. 6th Triennial Meeting ICOM, paper 81/15/5, $14 \mathrm{p}$.

Tiano, P., Bianchi, R., Gargani, G. and Vannucci, S. 1975. Research on the presence of sulphur-cycle bacteria in the stone of some historical buildings in Florence. Plant Soil 43: 211-217.

Van der Marel, H.W. and Beutelspacher, H. 1976. Atlas of Infrared Spectroscopy of Clay Minerals and their Admixtures. Elsevier, Amsterdam.

Vreeland, R.H. and Hochstein, L.I. 1992. The Biology of Halophilic Bacteria. CRC Press, Boca Raton, Florida. 